\title{
Deproteinized plant juice as part of circular economy: A short review and brief experimental data
}

\author{
Döme Barna - Ibolya Oláhné Tóth - Miklós Gábor Fári - Nóra Bákonyi \\ University of Debrecen, Department of Agricultural Botany, Crop Physiology and Biotechnology, Böszörményi str. 138 H-4032 Debrecen \\ Hungary \\ barnadoeme@gmail.com
}

\begin{abstract}
SUMMARY
As the population of the Earth is constantly growing it generates an unmet demand for protein, which is an urgent problem. The protein extraction process is a potential solution, which offers high-quality plant protein suitable for animal and human nutrition at a favorable price. The process used within our project produces green juice from the green alfalfa biomass through pressing. After the coagulation of protein from this green juice, the by-product is called DPJ (Deproteinized Plant Juices) or brown juice. Our preliminary results match the international literature, namely that brown juice take up as much as 50\% of the fresh biomass in weight. To utilize this by-product is a crucial part of the process to make it environmental-friendly and financially viable as well. The examined brown juice samples came from a small-scale experiment of alfalfa cultivars carried out in the experimental farm at the University of Debrecen. According to our preliminary results, brown juice has high macro- and micronutrient values, furthermore, it has a potentially high amount of antioxidant compounds. The study highlights that brown juice is suitable as an ingredient in microbiological media, in plant nutrition as a supplementary solution, for feedstock and for preparing human food supplements or functional foods. The potential utilization of all biorefinery products makes it a very appropriate technology for today's challenges.
\end{abstract}

Keywords: deproteinized plant juice, brown juice, circular economy, sustainable development

\section{INTRODUCTION}

The growth of the human population on Earth, coupled with the change from traditional to a western/international diet in the developing countries the demand for quality protein sources is rapidly rising. The human population reaches numbers never seen before and predicted to be near 10 billion in 2050 (Ehrlich and Harte, 2015) and is expected to keep growing (Gerland et al., 2014). Circular economy slowly becomes a trending business model worldwide as the leading economical countries start to implement this concept. Research programmes have started in China, the US and South Korea to boost remanufacturing and reuse (Stahel, 2016). China is the leader in this process as the concept of circular economy is already encapsulated in their last two fiveyear plans (Murray et al., 2017). However, the country has a strong reason to do so since its lands are steadily deteriorating (Han and He, 2011) and the environment in certain parts of China is so polluted it is hardly a viable place for humans. With sustainable development being a major concept of the last century and still trending in the new millennium we need to adjust our production to make it sustainable in the long-term. Circular economy aims to help this case by providing a scheme based on nature itself. We know that there are cycles in nature e.g. water cycle, air cycle, soil cycle, carbon cycle etc. In the nutrient cycle producers have a major role (Jurgilevich et al., 2016). Basically, every particle in such a dynamic cycle is moving constantly and regularly returns to its starting state. Based on natural cycles is the circular economy which is already adopted in China's industry and slowly penetrating to the other developing countries and to the developed part of the world as well. The main aim of this concept can be summarized in three words: reduce, reuse, recycle.

Thomsen et al. (2003) defined the biorefineries as technological cycle processing all the generated raw materials that focuses on sustainable production creating further waste (Popp et al., 2014). 90\% soybean meal used in Hungary is from import sources (Popp et al., 2014). The Proteomill program started in 2001 lead by Tedej ltd. its main scope being the research of leaf proteins (Fári, 2016) which can substitute the soy protein. The process is based on the idea of Ereky Károly and evolved throughout the years to fit into the actual state of the technology and social environment (Kohler and Bickoff, 1971; Fári et al., 2015). During the process examined in this research we got the main product called LPC (leaf protein concentrate) and its variations on different carriers and we got two byproducts, namely fiber (PCR-press crop residue) and brown juice. Brown juice is mentioned in some articles as DPJ (Deproteinized Plant Juice) (Pirie, 1942; Iliyas, 2014) or deproteinized leaf extracts or leaf juice, deproteinized whey (Jadhav et al., 2019) as a byproduct of plant protein producing technologies. The DPJ takes up to $50 \%$ of the fresh biomass is separated after the coagulation of proteins. Its colour varies from yellow to dark brown with occasional greenish colour depending on the particular process. The brown juice disposed without any treatment is costly and wastes the precious material rich in various organic components and inorganic elements (Pirie, 1971; Salah, 2007; Grela and Pietrzak, 2014; Popp et al., 2014; Obi et al., 2016). The DPJ has a dry-matter content ranging from 4 to $6 \%$ depending on species, cultivar, phenophase, processing technology. The high values make the brown juice a very valuable product, meanwhile it could be harmful directly poured into nature. DPJ released into the 
environment can enhance eutrophication and promote high nitrate levels due to its high content of minerals and organic substances. To avoid this negative environmental impact there are strict regulations in Denmark (Holmberg, 2016). Certain approaches aimed at using these valuable by-products (Lamont et al., 2017; Santamaria, 2015; Shende and Gogle, 2016; Thomsen and Kiel, 2008; Weimer and Digmar, 2013) but quality papers on the actual utilization of brown juice are not numerous, to say the least.

\section{MATERIALS AND METHODS}

The field experiment which provided us with raw material of fresh alfalfa (Medicago spp.) started in 2017 with seven commercial cultivars (Hunor-40, Dimitra, Jozsó, Tápiószelei-1, Olimpia, Expressz, Legend) at the experimental farm of the University of Debrecen. Furthermore, our industrial partner, Tedej Ltd. has large-scale production so we can easily transfer the technology to actual production. Together with the company we established a pilot-scale biorefinery to model the process. The process based on the technology (Patent No. P1800041 and PCT/HU2019/050003 international Patent/DETTI176/) shown on Figure 1 is made up from 2 steps: pressing and separation of green juice and fiber fraction (1) and precipitation of proteins and filtering, thus separating the LPC (Leaf Protein Concentrate, main product) from the brown juice fraction (2). In our experiment we used an Angel Juicer (5500, Angel Ltd., Praha, Czech Republic) machine pulp, press and separate green juice and fiber fractions. In the second step the green juice was heated to $80{ }^{\circ} \mathrm{C}$ using microwave technology to make the proteins coagulate and obtain the LPC. The brown juice and LPC was separated by cotton cloth filter with a pore size of approximately 10 microns.

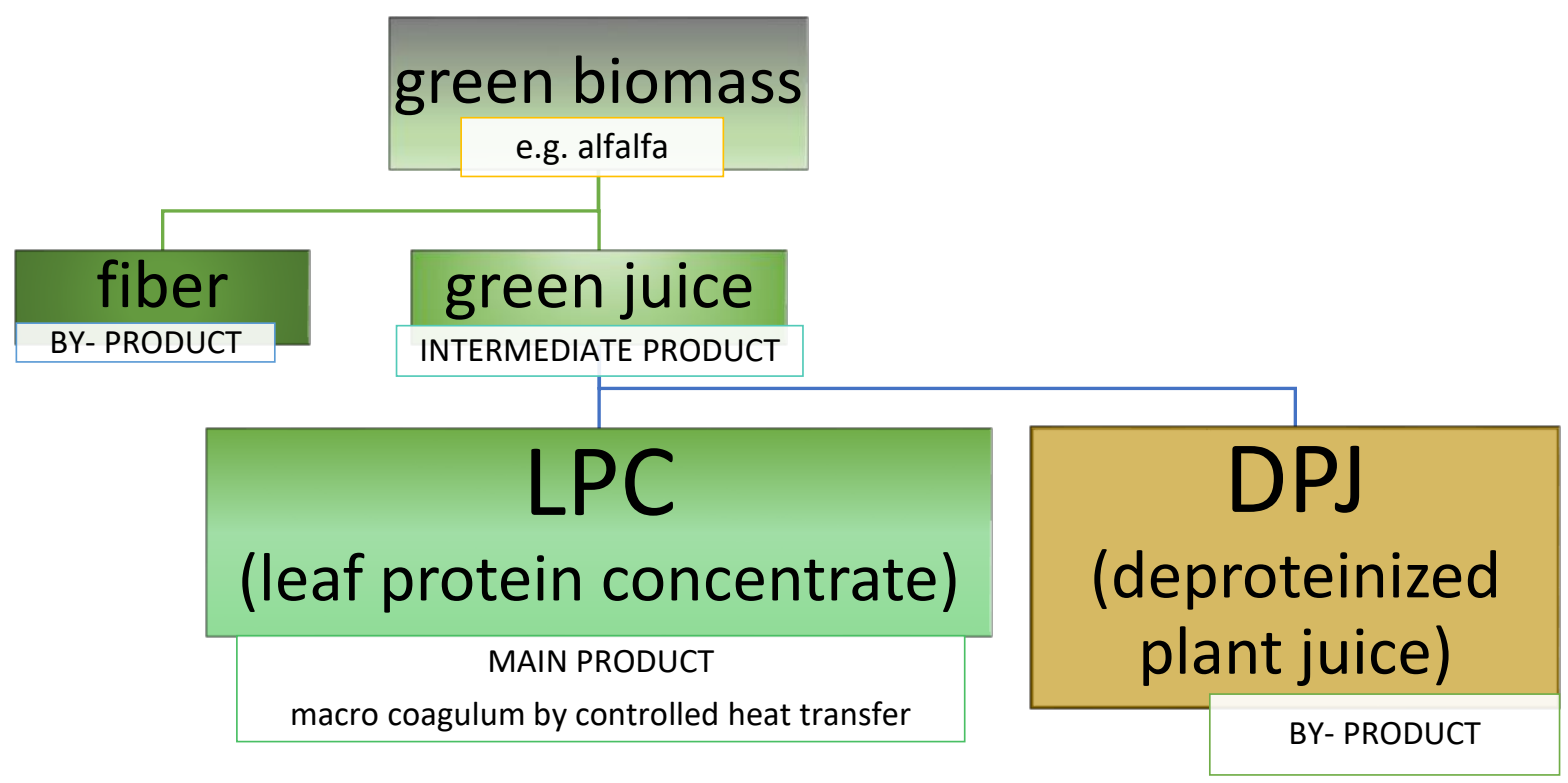

In this article we present the data of our small-scale experiment with the seven alfalfa cultivars, three repetitions, randomized block design and three sampling at different points of the year (31.07.2017 04.08.; 01.09.2017 - 08.09.; 28.05.2018-01.06.). We measured the weight of the different fractions produced from one kilogram of fresh alfalfa (Pioneer PA214, OHAUS).

The evaluation of the experimental data

Microsoft ${ }^{\circledR}$ Excel 2010 was used for the visual presentation of the data.

\section{RESULTS AND DISCUSSION}

After sampling the fresh alfalfa biomass, we followed the technology presented in Figure 1. After the wet fractionation and controlled coagulation, we processed and treated the samples of different fractions. The samples were measured separately according to the fractions originated from the different harvest times. Then the ratio of different products of wet fractionation was calculated, given the fresh weight of the alfalfa as $100 \%$. 


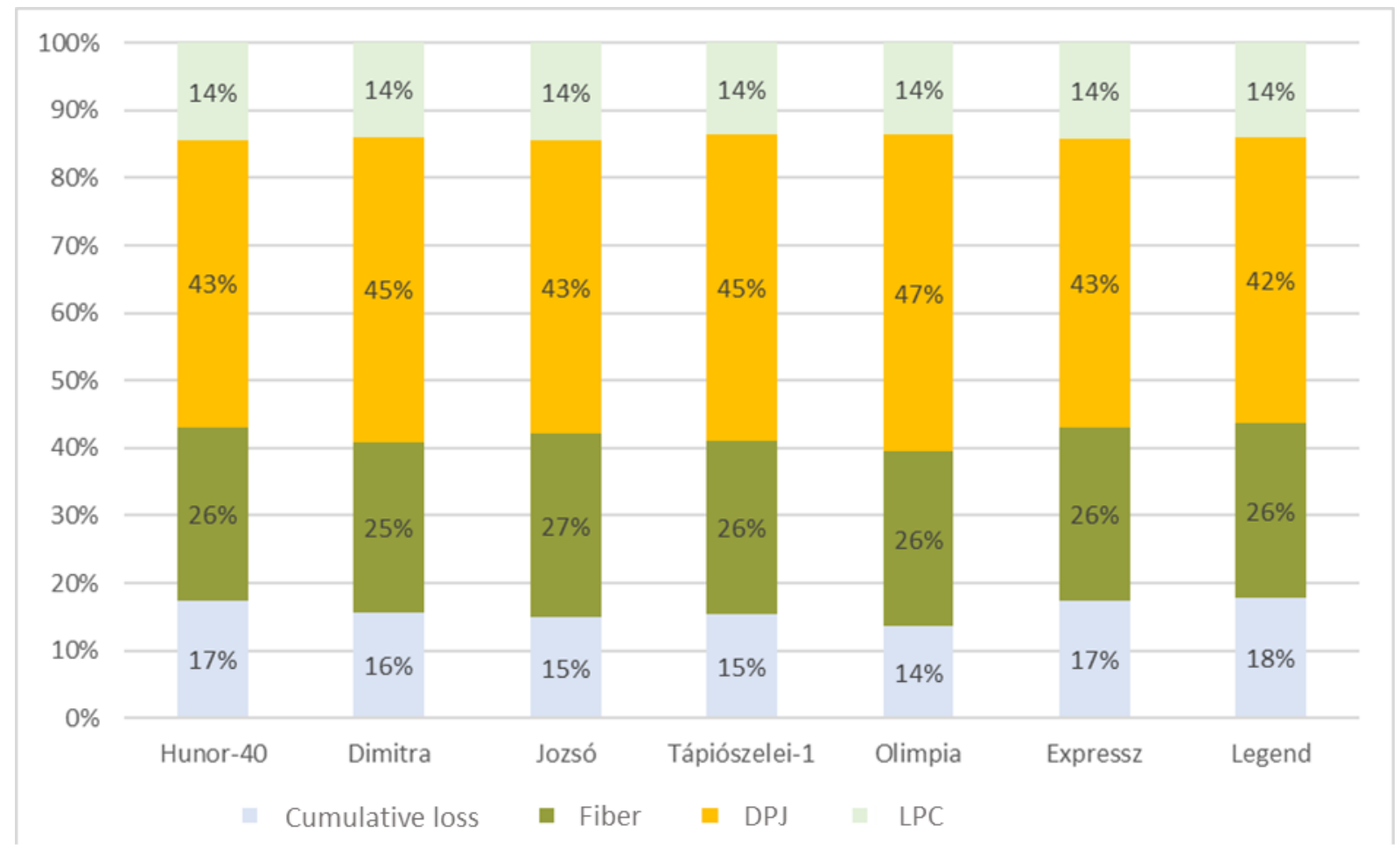

As Figure 2 shows the ratio of LPC (main product) was equal $(14 \mathrm{~m} / \mathrm{m} \%)$ from all cultivars. The fiber fraction ranges from 25 to $27 \%$. The DPJ fraction can take up almost half of the fresh biomass. It was between 42 and $47 \%$ on average. The average of the three harvests of 'Olimpia' resulted the highest DPJ ratio, $47 \%$. Probably this cultivar was in a more juvenile stage and had softer tissues. On the other hand, the cultivar 'Jozsó' had the highest fiber ratio on average $(27 \%)$ and a relatively lower amount of DPJ $(43 \%)$. At the moment, we also must count with a significant amount of cumulative loss, which can be a result of the premature and continuously developed technology process.

Our data underscore the importance of brown juice utilization since it is nearly $50 \%(\mathrm{~m} / \mathrm{m})$ of the fresh biomass. These results are similar to that of KohlerBickoff (1971), Pirie (1942), showing that brown juice is generated in large quantities. In our preliminary results (Bákonyi et al., 2018) and in the international literature there are limited information regarding the content of the brown juice, minerals, in particular (Shende and Gogle, 2016). These high values make the brown juice a very valuable product. According to our previously published data (Bákonyi et al., 2018; 2020), it contains significant amounts of macro- and microelements, and sugars as well.

\section{CONCLUSIONS}

The constant growth of human population on Earth and the rapidly growing protein demand tightly connected and mean a severe problem for the current and future generations. We are in dire need to reduce our negative impact on the environment. This brings up new problems to solve. Circular economy can help us to make our production somewhat more sustainable. Our green biorefinery process, called Proteomill fits well into this concept by using all the products coming from the wet-fractionation of green biomass. In our study we examined the amount of products generated by the presented technology, on the average of 3 harvest times, with 3 repeats each $(n=9)$ with 7 cultivars. DPJ, which is a by-product generated in great volumes (42-47 $\mathrm{m} / \mathrm{m} \%$ of fresh biomass). The ratio of the main product, LPC is $14 \mathrm{~m} / \mathrm{m} \%$. The process also produces a fiber fraction; its ratio ranged from 25 to 27 $\mathrm{m} / \mathrm{m} \%$. According to the international literature and our previous results DPJ has a great potential for utilization to make valuable products making the whole process environmental-friendly and profitable at the same time. Further investigations are on the track at our department and internationally as well (e.g. Denmark).

\section{ACKNOWLEDGEMENTS}

This research was financed by the "Higher Education Institutional Excellence Programme of the Ministry of Human Capacities in Hungary, within the framework of the biotechnology thematic program of the University of Debrecen". This research was financed also by the "Complex Rural Economic and Sustainable Development, Elaboration of its Service Networks in the Carpathian Basin (Project ID: EFOP3.6.2-16-2017-00001, Hungary)" research project. 
Also, support was given by Tempus Public Foundation (TPF), Hungary and Széchenyi 2020 under the GINOP2.2.1-15-2017-00051. and by the ÚNKP-19-3 new national excellence program of the ministry for innovation and technology.

\section{REFERENCES}

Bákonyi, N.-Kovács, Z.-O. Tóth, I.-Barna, D.-Fári, M.G.-Alshaal, T. (2018): To study the secondary elements contents (Ca, Mg, S) of deproteinized plant juice of selected alfalfa varieties at different harvest times. In: Pintér, Gábor; Zsiborács, Henrik; Csányi, Szilvia (szerk.) Arccal vagy háttal a jövőnek?: LX. Georgikon Napok, tanulmánykötet Keszthely, Magyarország: Pannon Egyetem Georgikon Kar, (2018) pp. 11-15., 5 p. ISBN: 9789639639928

Bákonyi, N.-Kisvarga, S.-Barna, D.-O. Tóth, I.-El-Ramady, H.Abdalla, N.-Kovács, S.-Rozbach, M.-Fehér, C.-Elhawat, N.Alshaal, T.-Fári, M.G. (2020): Chemical Traits of Fermented Alfalfa Brown Juice: Its Implications on Physiological, Biochemical, Anatomical, and Growth Parameters of Celosia. Agronomy 2020, 10, 247.

Ehrlich, P.R.-Harte, J. (2015): Opinion: To feed the world in 2050 will require a global revolution. Proc Natl Acad Sci U S A. 2015 Dec 1; 112(48): 14743-14744. Published online 2015 Dec 1. doi: 10.1073/pnas.1519841112

Fári, M.G.-Kralovánszky, U.P.-Popp, J. (2015): Biotechnológia Anno 1917-1919 Ereky Károly víziója az élettudomány alkalmazásáról/Biotechnology - Anno 1917-1919 The vision of Ereky Károly about the application of life science/. Szaktudás Kiadó Ház Zrt., Budapest. p. 137.

Fári, M.G. (2016): Kralovánszky U. Pál emlékezete. A hazai levélfehérje-kutatások újra indításának története /The story of the restart of Hungarian leaf protein research/. Mag Évkönyy 2016 (Szerk.: Oláh I.), p. 1-9.

Gerland, P.-Raftery, A.E.-Sevčíková, H.-Li, N.-Gu, D.Spoorenberg, T.-Alkem, L.-Fosdick, B.K.-Chunn, J.-Lalic, N.Bay, G.-Buettner, T.-Heilig, G.K.-Wilmoth, J. (2014): World population stabilization unlikely this century. Science (New York, N.Y.), 346(6206), 234-237. doi:10.1126/science.1257469

Grela, E.R.-Pietrzak, K. (2014): Production technology, chemical composition and use of alfalfa protein-xanthophyll concentrate as dietary supplement. Food processing and technology, 5, http://dx.doi.org/10.4172/2157-7110.1000373

Han, J.-He, X. (2011): Development of Circular Economy Is A Fundamental Way to Achieve Agriculture Sustainable Development in China, Energy Procedia, Volume 5, 2011, Pages 1530-1534, ISSN 1876-6102, https://doi.org/10.1016/j.egypro.2011.03.262.

Holmberg Olesen, M. (2016): The potential for lactic acid production in brown juice. Student projects - Project Library, Aalborg University, Denmark.

Iliyas, S. (2014): Effect of different flours on $\alpha$-amylase production. International Journal of Bioassays. 3. 3011-3015. 10.5251/ajsir.2014.5.3.104.109.

Jadhav, R.K.-Kadam, R.-Joshi D. (2019): Physiology of Gramineae Crops by Deproteinised Foliage Extract and its Influence on Photosynthetic Chemistry. The Journal of Phytochemistry. 110 (2019) 149-163.

Jurgilevich, A.-Birge, T.-Kentala-Lehtonen, J.-Korhonen-Kurki, K.-Pietikäinen, J.-Saikku, L.-Schösler, H. (2016): Transition towards Circular Economy in the Food System. Sustainability 2016, 8, 69 .
Kohler, G.O.-Bickoff, E.M. (1971): In Leaf Protein Its Agronomy, Preparation, Quality and Use (ed. Pirie, N. W.), IBP Hand Book No. 20, Blackwell Publication, Oxford, pp 69-77.

Lamont, J. R.-Wilkins, O.-Bywater-Ekegärd, M.-Smith, D.L. (2017): From yogurt to yield: Potential applications of lactic acid bacteria in plant production, Soil Biology and Biochemistry, Volume 111, 2017, Pages 1-9, ISSN 0038-0717, https://doi.org/10.1016/j.soilbio.2017.03.015.

Murray, A.-Skene, K.-Haynes, K. (2017): The Circular Economy: An Interdisciplinary Exploration of the Concept and Application in a Global Context. J Bus Ethics 140: 369. https://doi.org/10.1007/s10551-015-2693-2

Obi, F.O.-Ugwuishiwu, B.O.-Nwakaire J.N. (2016): Agricultural waste concept, generation, utilization and management. Nigerian Journal of Technology (NIJOTECH) Vol. 35, No. 4, October 2016, pp. 957-964. Electronic ISSN: 2467-8821 www.nijotech.comhttp://dx.doi.org/10.4314/njt.v35i4.34

Pirie, N.W. (1942): Green leaves as a source of protein and other nutrients. [Report on a meeting of Nutrition Panel of the Food Group of the Society of Chemical Industry, 11 February 1942] Nature, Lond. 149251

Pirie, N.W. (1971): Leaf protein: its agronomy, preparation, quality and use. (Pirie, N.W. Ed.), IBP Handbook No.20, Blackwell Scientific Publications, Oxford and Edinburgh.

Popp, J.-Lakner, Z.-Harangi-Rakos, M.-Fari, M. (2014): The effect of bioenergy expansion: food, energy, and environment, Renewable and Sustainable Energy Reviews 32, 559-578.

Santamaria, M. (2015): Protein recovery and biogas production from organically grown biomass: A green biorefinery concept.

Salah, E.H. (2007): Sustainability of Agricultural and Rural Waste Management, 1st Edition, Cradle-to-Cradle for Sustainable Development eBook ISBN: 9780080550145 Academic Press Published Date: 14th June 2007 Page Count: 424.

Shende, G.C.-Gogle, D.P. (2016): To study the effect of various concentration of deproteinized leaf juice (DPJ) of selected plants on growth of Aspergillus niger, Int. J. of Life Sciences, A6:186188.

Stahel, W. (2016): Circular economy. Nature. 531. 435-438. $10.1038 / 531435 \mathrm{a}$.

Thomsen, M.H.-Bech, D.-Kiel, P. (2003): Manufacturing of Stabilised Brown Juice for L-lysine production - from University Lab Scale over Pilot Scale to Industrial Production. Chem. Biochem. Eng. Q.18(1) 37-46. (2004)

Thomsen, M.H.-Kiel, P. (2008): Selection of lactic acid bacteria for acidification of brown juice (grass juice), with the aim of making a durable substrate for L-lysine fermentation. Journal of the Science of Food and Agriculture, 88, pp. 967-983.

Weimer, P.J.-Digman, M.F. (2013): Fermentation of alfalfa wetfractionation liquids to volatile fatty acids by Streptococcus bovis and Megasphaera elsdenii, Bioresource Technology, Volume 142, 2013, Pages 88-94, ISSN 0960-8524, httpsdoi.org10.1016j.biortech.2013.05.016. 